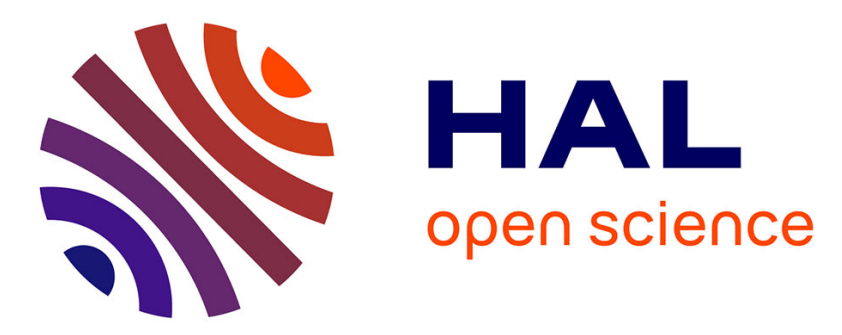

\title{
The consequences of the heritage experience in brand museums on the consumer-brand relationship
}

\author{
Mathilde Pulh, Rémi Mencarelli, Damien Chaney
}

\section{To cite this version:}

Mathilde Pulh, Rémi Mencarelli, Damien Chaney. The consequences of the heritage experience in brand museums on the consumer-brand relationship. European Journal of Marketing, 2019, 53 (10), pp.2193-2212. 10.1108/EJM-03-2017-0233 . halshs-02142424

\section{HAL Id: halshs-02142424 \\ https://shs.hal.science/halshs-02142424}

Submitted on 28 May 2019

HAL is a multi-disciplinary open access archive for the deposit and dissemination of scientific research documents, whether they are published or not. The documents may come from teaching and research institutions in France or abroad, or from public or private research centers.
L'archive ouverte pluridisciplinaire HAL, est destinée au dépôt et à la diffusion de documents scientifiques de niveau recherche, publiés ou non, émanant des établissements d'enseignement et de recherche français ou étrangers, des laboratoires publics ou privés. 
Pulh M., Mencarelli R., Chaney D., European Journal of Marketing

\section{The consequences of the heritage experience in brand museums on the consumer-brand relationship}

Purpose - This article investigates the consequences of the heritage experience in brand museums on the consumer-brand relationship. By highlighting its heritage within a museum, the brand proposes a specific experience that deserves attention because it is based on memory and communal identity, thus creating or strengthening a relationship with consumers.

Design/methodology/approach - Ethnographic case studies were conducted through direct observation and extensive interviews with 72 visitors at two brand museums, the Fallot Mustard Mill and the House of the Laughing Cow.

Findings - The results highlight the emergence / strengthening of the relationship between consumers and the brand through the development of intimacy with the brand and the emergence of supportive behaviors toward the brand in the form of commercial support, ambassadorship, and volunteering.

Research implications - By characterizing and articulating the different relational consequences of visiting a brand museum, this research contributes to the literature dedicated to heritage experiences in consumption contexts and to the literature dedicated to consumerbrand relationship in servicescapes.

Practical implications - The study shows the necessity of grounding "heritage" in the physical setting of the brand museum to create a meaningful experience for visitors and, in turn, a deep relationship. Managers should treat brand museums as a relational tool in the marketing strategy of the brand and approach them from the perspective of long-term profitability.

Originality/value - While the literature has examined the spectacular and aesthetic experiences brand museums offer, this study is the first to characterize the heritage experience and to document its consequences in terms of the consumer-brand relationship.

Keywords: Brand museums; Consumer-brand relationship; Heritage experience; Intimacy; Supportive behaviors

Paper type Research paper 


\section{Introduction}

The number of brand museums is constantly growing, whether they are local or global brand museums; in 2016, for example, both an IKEA museum in Sweden and a Nestlé museum in Switzerland opened their doors. While maintenance costs can be sufficiently high and several brand museums have closed in recent years, including France's Musée De La Moutarde Amora and England's Jaguar Heritage Museum, Italy's Museo Storico Alfa Romeo, which closed in 2011, reopened in 2015 with a new name referencing the heritage's ability to transcend time: the Museo Alfa Romeo - La macchina del tempo ${ }^{1}$. Broadly speaking, a brand museum refers to a "corporate facility with tangible objects and/or exhibits, displayed in a museum-like setting, that communicates the history, operations, and/or interests of a company to employees, guests, customers, and/or the public" (Danilov, 1992, p. 4).

Research in marketing identifies brand museums as specific kinds of flagship stores that include both a commercial and a heritage experience (Hollenbeck et al., 2008; Joy et al., 2014). Similar to a flagship store, a brand museum is overtly commercial, with a gift store, advertising, brand-oriented cultural artifacts, and entertainment through multi-sensory interactive displays (Kozinets et al., 2002). However, while a flagship brand store has an obvious commercial orientation (promote and sell), a brand museum typically emphasizes logics of exhibition and education. Brand museums also differ from flagship stores in that they communicate local and international history through their related cultural artifacts, situating their product offerings within a wider cultural context (Hollenbeck et al., 2008). At the same time, like regular museums, brand museums combine the desire to belong to a likeminded community with the importance of education and aesthetics, but contrary to a regular museum which serves society ${ }^{2}$, brand museums have the particularity to support a brand.

\footnotetext{
${ }^{1}$ This name translates to "Alfa Romeo Museum - The time machine".

${ }^{2}$ Museum definition of the International Council of Museums
} 
While the literature has investigated the commercial and spectacular experience offered by brand museums and its consequences in terms of brand meanings (e.g. Hollenbeck et al., 2008), the heritage experience and its consequences remains largely underexplored. Yet, by highlighting its heritage within a museum, the brand proposes a very specific experience that deserves attention because it is based on memory and communal identity through the transmission of the resulting collective memories (Lowenthal, 1998; Goulding, 2000), thus allowing it to generate changes in type and intensity of the relationship between the brand and consumers (Fournier, 1998; Debenedetti et al., 2014). As a consequence, we raise the following research question: how does the heritage experience shape the consumerbrand relationship?

To investigate our research question, we assess the heritage experience offered by two French brand museums and examine how consumers perceive the resulting setting. The results show that consumers perceive brand museums as places in which brands generously share their heritage, and thus they engage in a more intimate relationship and supportive behaviors with the brands. This research makes two contributions to the literature. First, it adds to the heritage-oriented brand experience literature by demonstrating the relational consequences of a heritage experience. Second, it contributes to the literature on commercial settings and supportive behaviors by showing that the characteristics of the heritage experience within brand museums create or reinforce the consumer-brand relationship. A review of the literature and a discussion of the methodology and findings follow. We conclude with a discussion of the results and the managerial implications for brand managers.

\section{Literature review}

Heritage-oriented branding experiences 
To avoid or, at the very least, ameliorate the predictability of commerce (Brakus et al., 2009), brands are seeking new sources of differentiation. To refresh their positioning and propose a different experience, more brands offer spectacular entertainment experiences amplified by techniques borrowed from museums and the art world, as illustrated by two streams of research.

The first stream evaluates the aesthetic experience that retail spaces provide, thus blurring the boundaries with museums. In their 2014 study of Louis Vuitton flagship stores in Hong Kong, Joy et al. (2014) examine how the brand incorporates art in its identity. Museological techniques (e.g. branded art pieces, artistic architecture, artistic events, curatorial attention of service personnel) can educate the public and provide a history of a given brand. In essence, luxury retail spaces such as Louis Vuitton stores become art institutions themselves, inviting consumers into a fantasy world made visible through gravitas conferred by art. Dion and Arnould (2011), Joy et al. (2014), and Dion and Borraz (2015) emphasize the interactivity between culture and retailing (Rodner and Preece, 2015), showing that luxury brandscapes create and disseminate aesthetic experience. In creating a museumlike retail experience, luxury brands employ salespeople whose roles overlap with those of guides and potentially curators or docents. This strategy transforms the consumer experience into an aesthetic experience based on features, such as the perception of products as art objects (Joy et al. 2014), which reinforces the brand aura, given the non-reproducible nature of art pieces, and modifies consumer behavior in the store to include those more typically displayed in an exhibition context.

The second stream of research is related to brand museums. Initially, Danilov (1992) and Nissley and Casey (2002) associated brand museums with functions of external communication (to bring proof of the quality and the know-how of the brand), internal communication (to create a link between employees), and even an additional sales channel. 
More recently, research has considered brand museums as hybrid places, born of the alliance between two apparently contradictory entities: the brand, which belongs to the commercial world, and the museum, which belongs to the non-commercial one (Byrom and Lehman, 2009). On the one hand, brand museums can be considered spectacular and re-enchanted commercial environments, offering an extraordinary experience (Ger and Belk, 1996; Kozinets et al., 2002); on the other hand, brand museums also simulate a museum with an education mission. In their investigation of the World of Coca-Cola in Atlanta, Georgia, Hollenbeck et al. (2008) show that brand museums use historical linkages and museum-like qualities combined with an education-driven mission to provide consumers with a meaningful vision of the brand.

While both streams of research offer numerous analogies with the museum world and in-depth insights into the brand meanings created, heritage characteristics appear only in the background of the analysis, whether they are aesthetic ideals associated with commercial places (Dion and Borraz, 2015) or education-driven missions associated with brand museums (Hollenbeck et al., 2008). Yet, when brands offer an experience based on technologies and devices inspired from the museum world (Hakala et al., 2011), they liken themselves to heritage and, through that, offer a heritage experience. Heritage refers to "the legacy of the natural and human world that society wishes to pass on to future generations" (Ashley, 2005, p. 5). According to Smith (2006), heritage is an object of the public sphere that is preserved and transmitted between generations. But cultural heritage is not a mechanical and neutral transmission of information from one generation to another (Lowenthal, 1998). It is important to consider it as a social construct which does not exist a priori (Arantes, 2007). As Smith explains (2006, p. 47), "heritage had to be experienced for it to be heritage". Heritage is thus a social construction through which an object moves from a private to a collective good status (Rautenberg, 2003). The term "heritage" thus refers both to production and reception 
processes. As a patrimony of the society or a social group, heritage is an extraordinary object arising from market relationships (Gauchet, 2005), at the heart of which identity transmission and construction mechanisms (Otnes and Maclaren, 2007) create social bonds within a family, a group, or a territory (Harrison, 2010). The collective dimension of heritage is therefore essential and serves as a support for individual and collective memories. The heritage experience stimulates the individual memory of consumers which becomes collective when shared with others. In staging its own heritage, the brand lays claim to cultural status through a temporal and geographic rooting (Lowenthal, 1998). The former allows the brand to present itself as a point of reference in society (Waitt, 2000), while the latter enables it to represent a territory (Park, 2010).

By allowing a heritage redefinition of the brand, a brand museum illustrates an 'ordinary' heritage (in contrast to an 'extraordinary' heritage) for everyday objects that are at the heart of groups' social identity construction (Grimwade and Carter, 2000; Cleere, 2001). Its aim is not simply to provide knowledge about the brand, but to transform it into "an idealized re-presentation of itself, wherein everything is considered not for its use but for its value as a potential museum artifact" (Di Giovine 2008, p. 261). In this context, the brand can endorse two heritage roles through the brand museum: an inter-generational memory role and a community representation role (Chaney et al., 2018). Thus, considering the different characteristics of the notion of heritage, we argue that when a brand proposes a heritage experience to consumers, it generates new symbolic meanings that are likely to create or strengthen the relationship between the consumer and the brand.

\section{Consumer-brand relationships in commercial settings}

The consumer-brand relationship literature addresses the long-term ties between consumers and brands (Fournier, 1998; Breivik and Thorbjørnsen, 2008). According to this approach, 
consumers buy a brand on a regular basis not because of its performance or perceived superiority but because they are involved in relationships with it that give meaning to their lives. For Fournier (1998), these meanings can be functional and emotional and have a strong identity resonance. Her pioneering work showcases the different modalities of the consumerbrand relationship. She puts forth a six-faceted construct to understand the relational quality between the consumer and the brand. This quality depends on the existence of an affective attachment (love/passion and self-connection), behavioral bonds (interdependence and commitment), and cognitive beliefs (intimacy and brand partner quality) that combine to contribute to the sustainability and strength of the relationship. The brand relationship perspective thus exerts a positive influence on consumer loyalty as a whole (e.g. Fournier and Yao, 1997; Hess and Story, 2005).

Applying this framework to commercial settings, previous research has shown that in such places, specific relationships between consumers and the brand form (Price and Arnould, 1999; Maclaran and Brown, 2005; Debenedetti et al., 2014). Indeed, taking an anthropomorphic view of the brand, the literature conceives of the brand as a person with whom it is possible to develop friendly and loving relationships (Fournier, 1998). For example, Price and Arnould (1999) describe a specific type of friendship that consumers develop with commercial places such as hairstylists, in which they not only spread positive word of mouth but also buy these providers groceries, send them cards, and even offer to babysit for them. In the same vein, Debenedetti et al. (2014) show that when consumers form an emotional bond with commercial places, they come to develop a sense of reciprocity, which leads them to engage in supportive behaviors including excessive tipping, ambassadorship toward the place, and volunteering.

Drawing from this body of research, we argue that when they propose a heritage experience within a brand museum, companies can bring the brand out of a purely 
commercial sphere to redefine the relationship with the consumer. Indeed, heritage is produced and legitimized as a separate and autonomous sphere of knowledge, value, and circulation, standing in opposition to the market, exchange value, and commodity circulation (Bourdieu, 1984). Through brand museums, companies give more than what the consumer is accustomed to receiving in a conventional commercial. By the staging of its heritage, the brand makes its history, know-how, and symbols accessible to consumers in a transmission logic whose message is "this is your heritage". The brand museum aims to share the heritage of the brand, which, by definition, is something that should be protected and transmitted (Smith, 2006; McDonald, 2011). In this engaging social context, the questions of whether and in what forms consumers value such experiences in terms of relationships with the brand remain unanswered. When experiencing the heritage of the brand during their visit to the museum, visitors are confronted with the social functions of heritage. In this context, do new forms of relationship with the brand appear and if so, what forms? Although all brand experiences do not necessarily lead to a particular relationship between the consumer and the brand, we hypothesize that the specific nature of the heritage experience allows to create or to strengthen consumer-brand bonds.

\section{Methodology}

To answer our research question, we employed two extended case studies; such research is particularly appropriate when the goal is to obtain an in-depth understanding of a contemporary phenomenon within a real-life context (Burawoy, 1998; Yin, 2013). Data were collected in two French brand museums: the Fallot Mustard Mill and the House of the Laughing Cow (see the Appendix). The food industry as a whole has significant enthusiasm for brand museums, given the strong relationships among food products, heritage, and cultural identity (Tellström et al., 2006). We selected our two brands specifically because of their 
differences; Fallot is a niche product marketed to connoisseurs, while the Laughing Cow is an industrial cheese product with a global presence and international notoriety. By exploring the heritage making of their respective brand museums, we were able to develop a comparative analysis to validate our findings, while accounting for the contextual effect of our case studies.

We triangulated our data using multiple methods and data sources, which strengthens the validity of our findings. We collected data using four complementary qualitative data collection methods. First, we reviewed the company-produced commercial and communication data (e.g. pamphlets, museum maps, websites, press releases) to assess how they promoted and staged the brand experience. We then conducted interviews with the museums' respective managers, focusing on the museums' origins and their implementation and positioning. The interviews lasted approximately 45 minutes and were recorded and transcribed.

Second, in line with research on consumer behavior in retail environments (Sherry, 1998; Hollenbeck et., 2008; Borghini et al., 2009; Kozinets et al., 2002; Joy et al., 2014), we employed traditional ethnographic techniques to prioritize facts and actions in real situations (Arnould and Wallendorf, 1994). We conducted 13 extended observational sessions (over a half day, either individually or as a group) in the two museums during a two-year period. During observations, we adopted a participant perspective and took notes and photographs, using the resulting data to triangulate our findings.

Third, we collected consumer narratives immediately after visits to attain immersive interpretations, in combination with field logs and guided introspection, following Wallendorf and Brucks (1993) and Sunderland and Denny (2007). We recruited participants directly at the site at the beginning of a visit: we gave each participant a notebook and pen to take notes during the visit about their thoughts, feelings, and moments of surprise and enjoyment. We 
also asked them to take photographs for their use in recalling their experiences. After the visit, we provided participants with a quiet area and writing desk. Briefly, the informants were asked to complete their narratives about their visit in the brand museum using their notes and photographs; no instructions about what to focus on were provided. While this method has potential drawbacks (self-selection amongst the participants, invitation of visitors to observe the museum in specific ways), this ethnographic technique gave visitors the opportunity to live the experience as freely as possible and allowed us to capture - not only a factual restitution - but also introspective impressions of the experience. This kind of writing introspection has also become easier to obtain because of the prevalence of reflexivity nowadays and people's growing inclination to talk about themselves (Olsen, 2012). Approximately 150 visitors were asked to participate; ultimately, we obtained 47 narratives (23 for the House of the Laughing Cow and 24 for the Fallot Mustard Mill). In total, we gathered 195 pages of narratives, averaging just over four pages per field log. We asked firsttime visitors (who represented the majority of participants), who had no prior knowledge of the museum, to work on spontaneous narratives. Previous visits to the museum could affect visitors' perceptions (e.g. leading them to focus on some aspects of their experience rather than others), which in turn could complicate identifying all the dimensions of their experiences. Table I and Table II list participants' respective characteristics. We further noted the geographic origins of the participants to guarantee heterogeneity. Because of the strong relationship between food products and territoriality (Wilson, 2006), visitor perceptions could vary greatly between consumers from the brand's place of origin and those from farther away. To achieve richness of the data, we ensured that the narratives were written by consumers with different relationships with the brand in terms of knowledge (connoisseurs and nonconnoisseurs), consumption (consumers and non-consumers), and image (negative and 
positive image) before the museum visit and in terms of immediate consumption in the museum gift shop after the visit (see Tables I and II).

Tables I and II about here

Fourth, to gain a deeper understanding of the experience, and particularly of its impact on the participants, we conducted 25 in-depth interviews with both first-time and repeat visitors, focusing on the relationship they developed with the brand. We recruited participants for these interviews directly at the end of the visit by collecting their e-mail addresses and telephone numbers to be able to contact them later. We interviewed them either face-to-face or using Skype as much as two months after their visits to assess lasting perceptions. The interviews were from 30 to 60 minutes in length and were recorded and transcribed. To minimize any risk of interviewer-induced bias, our research objective was never introduced. Participants were asked to describe their experiences in the museum and the resulting impact on their relationship with the brand and were free to guide the flow and content of the discussion. The informants represented a balance of men and women of various ages and occupations and with different profiles in terms of relationship with the brand and its products (before, during, and after the visit). Table III summarizes the characteristics of the informants.

Table III about here

We analyzed the collected qualitative material using comparative and hermeneutic methods (Spiggle, 1994; Thompson, 1997). The use of multiple methods, investigators, data sources, and the iteration process during the analysis allowed us to maintain an analytical distance from the field. Using an iteration process and progressive abstraction, we analyzed data varying between individual and collective interpretation, with the aim to obtain a shared understanding of uncovered phenomena (Arnould and Wallendorf, 1994). More precisely, the analysis consisted of two steps. In a first step, we identified and documented for each informant the consequences of the experience. Here, we took advantage of the richness of 
prior studies exploring consumer-brand relationships in commercial settings to guide our interpretation. In a second step, after identifying the positive relational consequences for each informant, we rebuilt the visit context and the salient features of the experience in the brand museum.

\section{Findings}

The analysis of our data suggests the existence of two main relational consequences following the visit of a brand museum: intimacy and supportive behaviors.

\section{The heritage experience as a source of intimacy between consumers and the brand}

Whether consumers know the brand before their visit or not, consume it or not, or appreciate it or not, the experience of visiting a brand museum creates, almost systematically, a real sense of intimacy with the brand. Intimacy refers to the oneness, bondeness and connectedness of a relationship, which culminates in a relationship in which people "experience warmth" (Yim et al., 2008). Intimacy is considered as a recurrent preference or a readiness for experiences of warm, close and communicative interaction with others (Mc Adams, 1982). It involves an interaction perceived as an end in itself, rather than a means to another end, and carried out within a close setting (Beetles and Harris, 2010).

In brand museums, different types of intimacy emerge between visitors and the brand. First, an intellectual intimacy is identified (Piorkowski and Cardone, 2000): it is gained from consumers knowledge (Akçura and Srinivasan, 2005) and refers to the disclosure of private information when the brand is revealing information that would not normally be revealed to others, outside that relationship (Hansen, 2003). Marie illustrated this kind of intimacy:

The Laughing Cow, everyone knows it, everyone or almost consumes it or has already consumed it, but we do not know what it is in fact. I thought it was made from crusts, 
according to all the gossips we hear around the product. But not at all. The visit erases all these rumors ... and it makes us closer to the brand because we know it better.

Thus, having access to the backstage and the brand's secrets generates a positive image of the brand (Narsey and Russell, 2013). Visitors value the brand's willingness to be transparent, which in turn generates confidence in the brand (Rose et al., 2016). As Clémence said about the Fallot Mustard Mill:

There is really a concern for transparency. The brand shows visitors how the product is manufactured. So, the company shows that it's not producing an industrial product with unknown ingredients. I know that the product is made in Burgundy. [...] Now I trust the brand, although I am aware that they have not told us everything. And behind that name there is a real tradition. I trust them because they have been honest with me. I do not want to be lied to about the quality of the product, especially now. So, now, I know that these are good products and that they will not disappoint me. Second, the data reveal the existence of social intimacy when consumers do not interact with a faceless organization but with a humanized brand thanks to individual representatives (Hollenbeck et al., 2008; Beetles and Harris, 2010). As Alexandra explained: After the visit, we lastly realize that behind there are people who work, who do and that's important. There are people who exist to produce it, to improve it. I became more aware about that after the visit. It's not just a brand. It is people. And thus, this visit made me want to support this product.

Brand can develop a form of social intimacy because it is incarnated throughout the museum tour by its founders but also by its employees and workers. It contributes to create relational connections with the brand (Fournier, 1998), leading visitors to consider the brand no longer as a mere commercial organization, but rather as a social structure. The third 
dimension of intimacy identified in our data is physical intimacy. While physical intimacy can relate to exchanges between visitors and the staff (Beetles and Harris, 2010), our findings suggest that in the context of the brand museum, it is mainly materialized through contact with products, machines, raw materials and employees as Laurène reported after visiting the Fallot Mustard Mill:

I did not think I would see the production line during the visit. But we could see the employees working and we understood what they were doing. You see the machines, the work that is actually done, the techniques and the technologies that are used. [...] They do everything to make you feel closer to them and to their product. You can touch everything during the visit and the museum explains the history, the production process. I think after the visit, the bet is successful: visitors feel at home. By having learned how things are made, they feel they belong to the Fallot Family. Fourth, a spiritual intimacy also appears in our data when visitors emphasize a sharing of values or beliefs with the brand (Piorkowski and Cardone, 2000; Trauer and Ryan, 2005). Antoine illustrated this point:

In the supermarket, when I see a product, I consider it as an industrial product which means mass production, industrial machinery. Here Fallot shows me it's not that at all. I realize that I had perceptions that did not fit with reality because of the discovery of the family, the handcrafted side and the human scale side of Fallot products. [...] I realize the values behind this production are consistent with my own values.

In this narrative, Antoine underscores the convergence of the brand's values with his own values and the evolution of his view on this industrial brand accordingly. This spiritual intimacy, as well as the intellectual, social and physical ones, reinforces the emotional connectedness between consumers and the brand and generates a meaningful relation for visitors (Fournier, 1998). From the entrance in the museum to the exit, interactions increase 
and participants become more and more intimate with the brand (Saavedra and Van Dyne, 1999). In consequence, as the relationship is perceived as an end in itself, intimacy can be the starting point for a stronger loyalty from consumers, who then support the brand through reciprocity (Fournier, 1998).

\section{The emergence of supportive behaviors toward the brand}

While the heritage experience offered in brand museums contributes to different types of intimacy between consumers and the brand, the data also suggest that some consumers engage more deeply in supportive behaviors. Visitors experience transmission of the brand's heritage and consider that the brand's primary goal is to inform and share rather than sell products, which in turn generates supportive behaviors. Indeed, the brand museum leads consumers to engage in supportive behaviors because of an established connection with the brand (Debenedetti et al., 2014). According to the informants, this willingness to support the brand consists of three behaviors: commercial support, ambassadorship, and volunteering.

Regarding the commercial support, purchasing can occur directly after the tour museum in the gift shop but also over time, through repeated purchases of brand products. Some of the visitors who did not buy directly from the museum shop became consumers of the brand after their visit. As evidenced by Daniel, a successful visit to the mustard Fallot makes people want to buy something:

We finish in a room where has been prepared for us a tasting of products: marbled ham, small toasts, tomatoes ... to soak in 3 different kinds of mustard. This moment is also a success: it is very pleasant after having [smelled the] mustard [...], after seeing the production, having heard the different flavors possible, to discover these products by tasting them. People seem to like it, the atmosphere is warm, we do not really want to leave, we taste, we listen to the explanations of our guide [...] it's really a nice 
conclusion. After this moment, we just desire to bring back a little something to share this experience with our loved ones or our friends who were not there.

Nathalie also expressed this form of support in the case of the House of the Laughing Cow by highlighting everything the brand has brought her of which she is therefore indebted: It was interesting to know the origin of the brand, the beginning of its story, of its myth of this cow who is a character who accompanied me all my youth. Some secrets of the story of this character have been revealed to us. During the visit, the guide told many stories about the Laughing Cow. I was surprised to hear that the name "Vache Qui Rit" comes from Valkyrie. [...] The visit, it touched me finally. This work that I can see during my visit. And now, when I'm going to buy products, I will say to myself: it's great because it's something I've visited. I'm even a little bit proud maybe. Yes, I am proud now to help a French product. I was consuming the products and now after the visit, I will consume even more.

Similar to Daniel and Nathalie, many of the participants expressed their support for a brand in the form of commitment through repeated purchase acts (Siu et al., 2013). These results also illustrate the dynamic nature of the relationship with the brand. Here, in response to a specific contextual environment - brand museum -, the relationship between the visitors and the brand evolves and changes after the visit (Fournier, 1998).

If visitors feel indebted to the brand, view it as a heritage tradition, and, as a result, support it commercially, that commitment may well extend to their familial and social circles, thus proving that transmission processes are at work. As a result, ambassadorship serves as a second form of supportive behaviors (Debenedetti et al., 2014). During their visit, many people mentioned their wish to be able to share their discoveries with their loved ones, as Elise formulated during her tour of the House of the Laughing Cow: 
I really enjoyed the "Grocery" section, where we discover all the old boxes, magazines and TV ads... It reminds me of school snacks when I was younger. [...] All these posters and sketches catch my eye. I think of my mother, I think of telling her about this visit, because I recognize these advertisements that I saw in old magazines, that she would recognize much better than me.

Here, the brand heritage experience is perceived by Elise as a source of individual memory that she wants to share and transmit through an active interpersonal communication. Beyond these forms of recommendations, some consumers choose to endorse an active role of ambassador of the brand freely and voluntarily (Schouten and McAlexander, 1995; Belk and Tumbat, 2005). For these visitors, the aim is to convey the discourse of the brand.

Ambassadorship also involves recruiting new consumers for the brand and its products themselves. The aim is not only to encourage their family or friends to visit but to convert them into connoisseurs of the brand on the basis of the heritage experience these new ambassadors previously lived in the brand museum. As with many of the visitors questioned, Frédéric, who is not from Burgundy and did not know about Fallot mustard before visiting its museum, has become a real spokesperson for the brand, constantly praising its merits to his close circle:

It is a good thing that the mustard is planted in Burgundy, that the verjuice used comes from Burgundy, that the production is also in Burgundy. That's good to see that the product is actually an authentic Burgundy product! I understand that they produce some good and beautiful items. To my parents and my friends who come in Burgundy, I tell them "the only real last mustard of Burgundy, is Fallot which is made in Beaune". And thus, they all leave with the little jar of mustard of Fallot in order to say that they bring back the real Dijon mustard too. And clearly this visit, for those who 
consume only Amora or Maille [two competing mustard brands in France], it can really change things. My mother who [has only eaten] Amora for 50 years, but who is really looking for spicy condiments, you make her do this visit, you explain [to] her everything and well it is sure that she becomes a fan of Fallot, she is totally converted!

Finally, supportive behaviors for some consumers exceed commercial support and ambassadorship, and though it is more unusual, some of the participants elected to volunteer for a brand. As Laetitia, who did not consume Laughing Cow products, revealed:

The reality of all this work that the House of the Laughing Cow has done in the heart of the Jura has really changed my relationship with the brand. At the beginning, I associated the museum with a showcase that allows the brand to be well established, baiting the consumers and encouraging them to spend more money, but then I realized the brand actually wanted to deploy its know-how, to serve the local population who live around the House. And finally, I no longer associate the museum with a commercial universe. And so I've decided to become involved in the non-professional working group that is discussing different architectural projects related to the reorganization of the House. I'm a voluntary worker. I feel really concerned with the project, the future tour in the museum, the future scenography of the House of the Laughing Cow. And I do it with a lot of pleasure.

Laetitia's comments indicate that she no longer sees the museum as a brand showcase, but rather as a place integrated into the local community. Through the museum, it is her perception of the whole brand that has changed. She chooses to give back to the brand through both purchases and actions, in essence serving as a liaison between the brand and the general public. Such dedication serves as the ultimate expression of any brand museum's goal. The majority of our respondents do not exhibit this specific supportive behavior. But 
relationships are multiplex phenomena and as underlined by Fournier (1998, p. 344), "they range across several dimensions and take many forms". More generally, these different kinds of supportive behavior (commercial support, ambassadorship, and volunteering) illustrate the existence of active and interdependent relationships between the brand and consumers (Fournier, 1998).

\section{Discussion}

By investigating the heritage experience in a brand museum, this research finds striking evidence of how this experience contributes to the emergence / strengthening of the consumer-brand relationship. For our informants, brand museum experience is characterized by intellectual stimulation, aesthetic pleasure, and emotional heritage (Chen, 2008; Heinich, 2011). As the results show, visitors perceive these spaces as real museums. They do not perceive the brand museum as a place developed by the brand for extrinsic material benefits. Visitors recognize the heritage values of the brand museum and in consequence the brand as a heritage artifact (Chaney et al., 2018). Consequently, the heritage experience resonates strongly with consumers, who develop a more intimate relationship and thus support the brand. The contribution of this work is the identification of a clear linkage between the heritage experience lived in the brand museum and the engagement of consumers in a close relationship with the brand through intellectual, physical, social, spiritual intimacy and supportive behaviors (commercial support, ambassadorship, and volunteering).

\section{Theoretical contributions}

This research makes two main contributions. First, it adds to the literature on heritageoriented branding experience, especially in a retailing context (Hollenbeck et al., 2008; Dion and Arnould, 2011; Joy et al., 2014; Dion and Borraz, 2015), by shedding light on the 
different relational consequences of this experience. While previous studies have provided insights into the brand meanings associated with a heritage experience, the literature is rather silent on how this experience shapes the consumer-brand relationship. Therefore, we take a different angle on the heritage experience by documenting its effect on the consumer-brand relationship. In a brand museum, for a small fee, visitors gain entry into privileged spaces, where they experience information, visual stimulation, historical provenance, artifacts of various kinds, interactive encounters, and free tastes of a brand's product line. While the activities in which visitors engage during brand museum tours are essentially involuntary, their responses to the brand museum experience are entirely voluntary. The possibilities of interacting at various levels with the brand and the heritage mechanisms - namely, transmission and representation-create intimacy and supportive behaviors, which in turn become an ingredient for the brand's long-term economic success.

We bring empirical evidence of these different manifestations of support to the brand. Informants' interviews suggest that the heritage experience yield deeper levels of intimacy with the brand (Fournier, 1998). Indeed, the heritage experience depicted by the informants is based on both aesthetics and the creation of a world of intellectual stimulation, an authentic and timeless universe. In this context, the brand museum tour generates various forms of intimacy through the disclosure of knowledge (intellectual intimacy), the interactions with individual representatives (social intimacy), the possibility of physical contacts (physical intimacy) and the sharing of values (spiritual intimacy) (Trauer and Ryan, 2005; Beetles and Harris, 2010). In all cases, the visitors treated the brand as a relational resource, which in turn created or reinforced the affective closeness between them and the brand. And because of the intrinsic nature of intimacy, visitors perceive the relationship as genuine and feel grateful to the museum. In consequence, they develop some supportive behaviors towards the brand (Debenedetti et al., 2014). The informants' interviews indicated first a commercial support of 
the brand. Indeed, some visitors helped support the brand through additional and/or exclusive purchases of the brand's products, not only after the museum tour but also over time through repeated purchases. The heritage experience encouraged them to give preferential treatment to the brand through commercial support (Price and Arnould, 1999). The second type of supportive behavior is to become an ambassador of the brand. Beyond active word of mouth, the study reveals that some visitors wanted to proselytize the brand to others (i.e. family and friends) by advocating for the brand and the brand museum (Schouten and McAlexander, 1995). Third, some visitors developed volunteer commitments. Beyond commercial norms, this meant developing collaborations with the brand and spending time and effort on the brand without compensation (Cova et al., 2015). In general, visitors valued the brand's willingness to be transparent (to show what is behind the scenes), the process of knowledge transmission, and the authenticity and veracity of the exhibition, which in turn encouraged them to support the brand.

Second, we also contribute to the literature on the link between commercial settings (e.g. hair salons, coffee houses, malls, restaurants) and supportive behaviors (Price and Arnould, 1999; Thompson and Arsel, 2004; Maclaran and Brown, 2005; Debenedetti et al., 2014) by highlighting the powerful characteristics of the heritage experience to shape and reinforce the consumer-brand relationship. By unpacking consumers' heritage experience, we investigate, chronicle, and demonstrate how brand museums, as a particular contextual servicescape, can deeply affect consumers, leading to a more intimate relationship and to supportive behaviors towards the brand. In the museum, the brand appears as a heritage artifact and consequently as a relational resource (through the inter-generational memory and community representation roles of heritage). The brand museum puts symbolism at the center of the relationship with individuals, which is at the opposite of a commercial space in which the relationships with things control individuals (Testart, 2001). In this context, our study 
shows how the consumer-brand relationship is shaped by the heritage experience even for visitors with no strong pre-existing relationship with the brand. Hence, the heritage experience can lead to meaningful and active consumer-brand relationships (Fournier, 1998). As the data indicate, the heritage experience in brand museums is complex. Visitors first live an intellectually exciting experience, as they would in any museum (Falk et al., 2012; Rodner and Preece, 2015); they perceive brand museums as places of knowledge transmission, which legitimizes these places' membership in the heritage register. Visitors then experience authenticity because they view the brand museums as places engaging in preservation and displaying non-denatured and original objects (Prentice, 2001). Some visitors also experience the brand myth through legends and anecdotes, thus satisfying their emotional aspirations (Brown et al., 2003). Furthermore, because consumers also live a sensory and aesthetic experience, brand museums extend the brand meaning from a utilitarian function to an aesthetic function (Joy et al., 2014). When visiting a brand museum, consumers are exposed to heritage and its functions, the transmission of memory between generations, and the representation of territories (Lowenthal, 1998; Goulding, 2000). These functions are universal, which means that they are collective identity markers that people use as resources (Holt, 2004). As we have demonstrated, it is these features that lead visitors to reconsider their relationship with the brand and to engage in supportive behaviors towards the brand.

Furthermore, it is also important to keep in mind that the consumer-brand relationship is idiosyncratic by nature (Holt, 1997). Each visitor exhibits different types of intimacy and supportive behaviors since relationships can take many forms and benefits (Fournier, 1998). It seems also necessary to underline that the consumer-brand relationship is a dynamic phenomenon. In our study, we observe the emergence / strengthening of the consumer-brand relationship in response to a specific contextual environment, i.e. the brand museum. But, it is 
likely to evolve and change over time depending on the other interactions with the brand (Fournier, 1998).

\section{Managerial implications}

From a managerial perspective, this study invites practitioners to consider the brand museum as a relational tool in the brand marketing strategy. The findings suggest that a brand museum and the heritage experience associated with it have a deep impact on the consumer-brand relationship. Following the brand museum tour, visitors engage in an intimate relationship and support the brand, mainly outside the museum even if they can support the brand by purchasing in the museum shop. From this perspective, this study suggests useful lessons for managers during and after the visit.

During the visit, the brand museum must immerse visitors in a full heritage experience to create a strong experience for consumers and, in turn, a deep relationship. For visitors to fully experience a brand museum, it must be intentionally designed to deliver a total heritage experience, capable of entrenching the brand in a territory and a community. For this, the museum must be able to demonstrate the authenticity of the brand to consumers (by giving them access to privileged information such as its production method, its recipe, and its knowhow); it must affirm its longevity and timelessness (by highlighting its birth, the work of its founders, its evolution over time, and its ability to follow the trends and expectations of consumers); and it must emphasize its aesthetic dimension (by exploiting it as a creation at the origin of emotions and sensations), while keeping some mystery to perpetuate the myth around the brand. The architecture, the atmosphere, the design, the presentations, and the activities surrounding the brand must be conceived in an all-encompassing and coherent way. In this context, a pitfall to avoid is to propose a partial heritage experience, in which the market dimension of the brand remains predominant. If consumers believe that the brand is 
developing this kind of environment for instrumental purposes (i.e. immediate commercial purposes), the relationship with the brand is likely to be damaged. The brand museum does not need to be large or expensive; however, managers should work to ground "heritage" in the physical setting, to create a meaningful experience for visitors.

After the brand museum visit, managers must preserve the relational dynamics created in this specific environment. In this perspective, managers need to cultivate the intimacy created with visitors by continuing to transmit private and personalized information echoing the heritage experience (intellectual intimacy) and by inviting visitors to brand events in - and beyond - brand museums to meet brand's representatives (social and physical intimacy). These actions, but also a more general communication based on the values of the brand, may reinforce spiritual intimacy with the brand. After the visit, managers should seek to maintain or even to amplify the role of brand ambassadors which emerged in the museum, to encourage and to develop supportive behaviors over time. Therefore, in addition to the in situ recruitment of ambassadors, the brand has to ensure that these visitors are regularly asked to relay information from the museum (on social networks, for example), to involve themselves in the museum activities and / or in the actions of the brand itself. To develop the brand museum beyond its territorial roots, it is important to develop these brand spokesperson roles and thus to foster word-of-mouth. Brands must however be careful and make sure that these tools are coherent with the heritage positioning not to reactivate the commercial dimensions of the brand. As such, the creation for structures similar to those existing in classical museums such as the Society of Friends of the Museum could be relevant as well as the development of volunteer programs.

Considering the idiosyncratic nature of the consumer-brand relationship, a pitfall to avoid is to develop these actions in a uniform and massive way. Managers must be able to distinguish different relational profiles such as, for example, 'brand enthusiasts' 
(ambassadors) or 'brand volunteers' (contributors), and to adapt their actions to these profiles. Overall, brand museums can be the starting point - especially for industrial brand such as the Laughing Cow - to engage in a deMcDonaldization of the relationship with consumers by offering an experience moving away from a purely commercial logic (Rizter and Jurgenson, 2010).

\section{References}

Akçura, M.T. and Srinivasan, K. (2005), "Research note: customer intimacy and cross-selling strategy”, Management Science, Vol. 51 No. 6, pp. 1007-1012.

Arantes, A. A. (2007), "Diversity, heritage and cultural politics", Theory, Culture \& Society, Vol. 24 No. 7-8, pp. 290-296.

Arnould, E.J. and Wallendorf, M. (1994), "Market-oriented ethnography: interpretation building and marketing strategy formulation", Journal of Marketing Research, Vol. 31 No. 4, pp. 484-504.

Ashley, S. (2005), "State authority and the public sphere: ideas on the changing role of the museum as a Canadian social institution", Museum and Society, Vol. 3 No. 1, pp. 5-17.

Beetles, A.C. and Harris, L.C. (2010), "The role of intimacy in service relationships: an exploration", Journal of Services Marketing, Vol. 24 N 5, pp. 347-358.

Belk, R.W. and Tumbat, G. (2005), “The cult of Macintosh”, Consumption Markets \& Culture, Vol. 8 No. 3, pp. 205-217.

Borghini S., Diamond N., Kozinets R.V., McGrath M.A., Muniz Jr., A.M. and Sherry Jr., J.F. (2009), "Why are themed brandstores so powerful? Retail brand ideology at American girl place", Journal of Retailing, Vol. 85 No. 3, pp. 363-375.

Bourdieu, P. (1984), Distinction: A Social Critique of the Judgement of Taste, Harvard University Press, Cambridge, MA.

Brakus, J.J., Schmitt, B.H. and Zarantonello, L. (2009), "Brand experience: what is it? How is it measured? Does it affect loyalty?", Journal of Marketing, Vol. 73 No. 3, pp. 52-68.

Breivik, E. and Thorbjørnsen, H. (2008), "Consumer brand relationships: an investigation of two alternative models", Journal of the Academy of Marketing Science, Vol. 36 No. 4, pp. 443-472. 
Brown, S., Kozinets R.V. and Sherry Jr., J.F. (2003), “Teaching old brands new tricks: retro branding and the revival of brand meaning", Journal of Marketing, Vol. 67 No. 3, pp. 1933.

Burawoy, M. (1998), “The Extended case method”, Sociological Theory, Vol. 16 No. 1, pp. 4-34

Byrom, J. and Lehman, K. (2009), "Coopers Brewery: heritage and innovation within a family firm", Marketing Intelligence \& Planning, Vol. 27 No. 4, pp. 516-523.

Chaney, D., Pulh, M. and Mencarelli, R. (2018), "When the arts inspire businesses: Museums as a heritage redefinition tool of brands", Journal of Business Research, vol. 85, pp. 452458.

Chen, Y. (2008), "Possession and access: consumer desires and value perceptions regarding contemporary art collection and exhibit visits", Journal of Consumer Research, Vol. 35 No. 6, pp. 925-940.

Cleere, H. (2001), The uneasy bedfellows: Universality and cultural heritage. In R. Layton, P. Stone, \& J. Thomas (Eds.), Destruction and conservation of cultural property (pp. 2229), Routledge, London.

Cova, B., Pace, S. and Skålén, P. (2015), "Brand volunteering: value co-creation with unpaid consumers", Marketing Theory, Vol. 15 No. 4, pp. 465-485.

Danilov, V.J. (1992), A Planning Guide for Corporate Museums, Galleries, and Visitor Centers, Greenwood Press, Westport, CT.

Debenedetti, A., Oppewal, H. and Arsel, Z. (2014), "Place attachment in commercial settings: a gift economy perspective”, Journal of Consumer Research, Vol.. 40 No. 5, pp. 904923.

Di Giovine, M. A. (2008), The heritage-scape: UNESCO, world heritage, and tourism, Lexington Books, Lanham.

Dion, D. and Arnould, E. (2011), "Retail luxury strategy: assembling charisma through art and magic", Journal of Retailing, Vol. 87 No. 4, pp. 502-520.

Dion, D. and Borraz, S. (2015), "Managing heritage brands: a study of the sacralization of heritage stores in the luxury industry", Journal of Retailing and Consumer Services, Vol. 22 , pp. $77-84$.

Falk, J.H., Ballantyne, R., Packer, J. and Benckendorff, P. (2012), “Travel and learning: a neglected tourism research area", Annals of Tourism Research, Vol. 39 No. 2, pp. 908927. 
Fournier, S. (1998), "Consumers and their brands: developing relationship theory in consumer research”, Journal of Consumer Research, Vol. 24 No. 4, pp. 343-373.

Fournier, S. and Yao, J.L. (1997), "Reviving brand loyalty: a reconceptualization within the framework of consumer-brand relationships", International Journal of Research in Marketing, Vol. 14 No. 5, pp. 451-472.

Gauchet, M. (2005), Le Désenchantement du monde. Une histoire politique de la religion, Gallimard, Paris.

Ger, G. and Belk, R.W. (1996), "I'd like to buy the world a Coke: consumptionscapes of the 'less affluent world'”, Journal of Consumer Policy, Vol. 19 No. 3, pp. 271-304.

Goulding, C. (2000), "The commodification of the past, postmodern pastiche, and the search for authentic experiences at contemporary heritage attractions", European Journal of Marketing, Vol. 34 No. 7, pp. 835-853.

Grimwade, G. and Carter, B. (2000), "Managing small heritage sites with interpretation and community involvement", International Journal of Heritage Studies, Vol. 6, No. 1, pp. $33-48$.

Hakala, U., Lätti S. and Sandberg B. (2011), “Operationalizing brand heritage and cultural heritage", Journal of Product and Brand Management, Vol. 20 No. 6, pp. 447-456.

Hansen, H. (2003), “Antecedents to consumers' disclosing intimacy with service employees”, Journal of Services Marketing, Vol. 17 No. 6, pp. 573-588.

Harrison, R. (2010), Understanding the Politics of Heritage, Manchester University Press, Manchester.

Heinich, N. (2011), “The making of cultural heritage”, Nordic Journal of Aesthetics, Vol. 22 No. 40/41, pp. 119-128.

Hess, J. and Story, J. (2005), “Trust-based commitment: multidimensional consumer-brand relationships", Journal of Consumer Marketing, Vol. 22 No. 6, pp. 313-322.

Hollenbeck, C.R., Peters, C., and Zinkhan, G.M. (2008), "Retail spectacles and brand meaning: insights from a brand museum case study", Journal of Retailing, Vol. 84 No. 3, pp. 334-353.

Holt, D.B. (1997), "Poststructuralist lifestyle analysis: Conceptualizing the social patterning of consumption in postmodernity", Journal of Consumer Research, Vol. 23 No. 4, pp. 326-350.

Holt, D.B. (2004), How Brands Become Icons: The Principles of Cultural Branding, Harvard Business Press, Cambridge, MA. 
Joy, A., Wang, J.J., Chan, T.S., Sherry, J.F. and Cui, G. (2014), "M (Art) worlds: consumer perceptions of how luxury brand stores become art institutions", Journal of Retailing, Vol. 90 No. 3, pp. 347-364.

Kozinets, R.V., Sherry Jr., J.F., DeBerry-Spence B., Duhachek A., Nuttavuthisit K. and Storm D. (2002), "Themed flagship brand stores in the new millennium: theory, practice, prospects", Journal of Retailing, Vol. 78 No. 1, pp. 17-29.

Lowenthal, D. (1998), The Heritage Crusade and the Spoils of History, Cambridge University Press, New York, NY.

Maclaran, P. and Brown S. (2005), "The center cannot hold: consuming the utopian marketplace,” Journal of Consumer Research, 32 No. 2, pp. 311-323.

McAdams, D.P. (1982), "Intimacy motivation”, in Stewart, A.J. (Ed.), Motivation and Society, Jossey-Bass, San Francisco, CA, pp. 133-71.

McDonald, H. (2011), "Understanding the antecedents to public interest and engagement with heritage", European Journal of Marketing, Vol. 45 No. 5, pp. 780-804.

Narsey, V. and Russell, C.-A. (2013), "Behind the revealed brand: exploring the brand backstory experience", Research in Consumer Behavior, Vol. 15, pp. 297-323.

Nissley, N. and Casey, A. (2002), "Viewing corporate museums through the paradigmatic lens of organizational memory: the politics of the exhibition", British Journal of Management, Vol. 13 No. 1, pp. 35-45.

Olsen, B. (2012), "Reflexive introspection on sharing gifts and shaping stories", Journal of Business Research, Vol. 65 No. 4, pp. 467-474.

Otnes, C. and Maclaren, P. (2007), "The consumption of cultural heritage among a British Royal family brand tribe", in Cova, B., Kozinets, R. and Shankar, A. (Eds.), Consumer Tribes, Elsevier, Oxford, MA, pp. 51-66.

Park, H.Y. (2010), “Heritage tourism: Emotional journeys into nationhood”, Annals of Tourism Research, Vol. 37 No. 1, pp. 116-135.

Piorkowski, G.K. and Cardone, S.S. (2000), Too close for comfort: exploring the risks of intimacy, Boulder Co: Perseus Publishing.

Prentice, R. (2001), "Experiential cultural tourism: museums and the marketing of the new romanticism of evoked authenticity", Museum Management and Curatorship, Vol. 19 No. 1, pp. 5-26.

Price, L.L. and Arnould, E.J. (1999), “Commercial friendships: service provider-client relationships in context", Journal of Marketing, Vol. 63 No. 4, pp. 38-56.

Rautenberg, M. (2003), La rupture patrimoniale, Grenoble : A la Croisée. 
Ritzer, G. and Jurgenson, N. (2010), "Production, Consumption, Prosumption: The Nature of Capitalism in the Age of the Digital "Prosumer"', Journal of Consumer Culture, Vol. 10 No. 1, 13-36.

Rodner, V. L. and Preece, C. (2015), “Tainted museums: 'selling out' cultural institutions", International Journal of Nonprofit and Voluntary Sector Marketing, Vol. 20 No. 2, pp. 149-169.

Rose, G.M., Merchant, A., Orth, U.R. and Horstmann, F. (2016), "Emphasizing brand heritage: does it work? And how?", Journal of Business Research, Vol. 69 No. 2, pp. 936-943.

Saavedra, R. and Van Dyne, L. (1999), "Social exchange and emotional investment in work groups", Motivation and Emotion, Vol. 23 No. 2, pp. 105-123.

Schouten, J.W. and McAlexander, J. H. (1995), "Subcultures of consumption: an ethnography of the new bikers", Journal of Consumer Research, Vol. 22 No. 1, pp. 43-61.

Sherry Jr., J.F. (1998), ServiceScapes: The Concept of Place in Contemporary Markets, NTC Business Books, Lincolnwood, IL.

Siu, N.Y.M., Zhang, T.J.F., Dong, P. and Kwan, H.Y. (2013), "New service bonds and customer value in customer relationship management: the case of museum visitors", Tourism Management, Vol. 36, pp. 293-303.

Smith, L. (2006), Uses of Heritage, Routledge, New York, NY.

Spiggle, S. (1994), “Analysis and interpretation of qualitative data in consumer research", Journal of Consumer Research, Vol. 21 No. 3, pp. 491-503.

Sunderland, P.L. and Denny, R.M.T. (2007), Doing Anthropology in Consumer Research, Left Coast Press, Walnut Creek, CA.

Tellström, R., Gustafsson, I.B. and Mossberg, L. (2006), “Consuming heritage: the use of local food culture in branding”, Place Branding and Public Diplomacy, Vol. 2 No. 2, pp. 130-143.

Thompson, C.J. (1997), "Interpreting consumers: a hermeneutical framework for deriving marketing insights from the texts of consumers' consumption stories", Journal of Marketing Research, Vol. 34, pp. 438-455.

Thompson, C.J. and Arsel, Z. (2004), “The Starbucks brandscape and consumers' (anticorporate) experiences of glocalization", Journal of Consumer Research, Vol. 31 No. 3, pp. 631-642. 
Trauer, B. and Ryan, C. (2005), "Destination image, romance and place experience - an application of intimacy theory in tourism”, Tourism Management, Vol. 26 No. 4, pp. 481491.

Waitt, G. (2000), "Consuming heritage: perceived historical authenticity", Annals of Tourism Research, Vol. 27 No. 4, pp. 835-862.

Wallendorf, M. and Brucks, M. (1993), "Introspection in consumer research: implementation and implications", Journal of Consumer Research, Vol. 20 No. 3, pp. 339-359.

Wilson, T.M. (2006), "Food, drink and identity in Europe: consumption and the construction of local, national and cosmopolitan culture", European Studies: a Journal of European Culture, History and Politics, Vol. 22 No. 1, pp. 11-29.

Yim, C.K., Tse, D.K., and Chan, K.W. (2008), "Strengthening customer loyalty through intimacy and passion: Roles of customer-firm affection and customer-staff relationships in services", Journal of Marketing Research, Vol. 45 No. 6, pp. 741-756.

Yin, R.K. (2013), Case study Research: Design and Methods, Sage Publications, New York, NY. 


\section{Appendix. Presentation of the two brand museums}

Presentation of the Fallot Mustard Mill: Fallot is a family business founded in 1840 in Beaune (Burgundy, France) that, true to its heritage, continues to pulverize mustard seeds at the grindstone. Such respect for tradition allows Fallot to benefit from a high-end market positioning. In 2003, Fallot opened a brand museum and developed a "discovery path [...] using [the] most modern museum techniques" in which visitors can "discover the history of the Burgundy mustard like [they have] never seen it before" (http://www.fallot.com/en/la-moutarderiefallot/). This museum offers a tasting area and two distinct tours (http://www.fallot.com/en/):

- "Decouvertes" tour: "The Discovery tour is a fun interactive circuit in a timeless setting which will titillate your sense of smell like no other. It takes visitors on a journey through the ages, teaching them about the techniques and traditions associated with mustard and its history".

- "Sensational Experience" tour: "While La Moutarderie Fallot has been able to preserve its traditional and ancestral manufacturing methods [...], it is with pride that we now invite you to come and discover new experiences and sensations at a venue which truly befits the $21^{s}$ century".

Presentation of the "Maison de la Vache qui rit"® (the House of the Laughing Cow®): The Laughing Cow is a brand born in 1921, owned by the Bel Group (founded in 1865), which specializes in various cheeses. The brand was created in the French region of Jura and benefits from an international reputation, with products available in 120 countries, due to its industrial development and global marketing strategy. In 2009, the group opened its brand museum in Lons-le-Saunier (Franche-Comte, France), a 27,000-square-foot museum dedicated specifically to the Laughing Cow brand. It's general layout has been recently completely redesigned in order to offer "a place to share, a meeting place, in a dialogue constantly re-examined between historical and scientific heritage, contemporary creation and participatory approaches"(press release - june 2018). The museum's website (http://www.lamaisondelavachequirit.com) states that "the tour begins with the historic space of the cellars that presents the brand's adventure since its creation"; the visitor can also "discover the BelisEp Group's industrial expertise with the manufacturing process of the Laughing Cow". The museum offers a shop, a cooking worshop, a "wachkyries café" and "the small cauldron" a restaurant located in the roof top of the House of the Laughing Cow. It's Manager said that the museum was conceived as a place of "living and amazement... [to create] "a very emotional relationship between the brand and its visitors. The project has been reviewed in order to meet even more the expectations of visitors, and therefore communicates even more about manufacturing, packagings...". 
